\title{
Sexual Maturity of Male Chickens According To Early Response of Semen Collection
}

\author{
${ }^{*}$ Abou-Elewa E.M. ${ }^{1}$; A.A. Enab ${ }^{1}$ and Abdou, F.H ${ }^{1}$ \\ ${ }_{1}^{1}$ Poultry Production Department, Faculty of Agriculture, Menoufia University, Shebin El-Kom 32511, \\ Menoufia, Egypt.) \\ Corresponding Author: Abou-Elewa E.M
}

\begin{abstract}
Determination of age at sexual maturity trait is very important before selection of breeding males of chickens without depending on female. A total of 44 males and 84 females at 13wks of age of Norfa chickens were used for this study. The aim of this study was to determine age at sexual maturity of cocks depending on the first response of semen collecting and to characterize some of semen parameters at the same time. Semen was collected by abdominal massage method. Studied traits were age at sexual maturity, body weight at sexual maturity, fertility, hatchability and egg weight at sexual maturity. Also, some of semen parameters included volume ,PH, concentration of sperms per ml, motility and percent of normal shape were studied. Males were divided into three groups; the first was early sexual maturity (G1) $\leq$ mean-1S.D,the second was the moderate sexual maturity (G2)which equal to mean or not significant different with mean and the third was the late

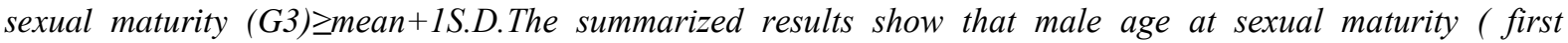
response of semen collecting means were (AFR)) $91 \pm 0.0,104.7 \pm 0.55$ and $120.17 \pm 1.2 d$. of $G 1, G 2$ and G3 respectively, There were highly significant differences among three groups. Female age at sexual maturity means were $144 \pm 162.05 d$., $162.05 \pm 0.4 d$. and $196 \pm 6.3 d$. of $G 1, G 2$ and $G 3$ respectively. with highly significant differences among three groups. There were no significance differences in semen quality traits at sexual maturity among all groups. Fertility in early group was greater than others. Hatchability in early group was greater than others. Males showed earlier sexual maturity than female, but differences between female groups were greater than male groups.
\end{abstract}

Keywords: chickens, sexual maturity, semen parameters.

Date of Submission: 15-06-2017

Date of acceptance: 15-07-2017

\section{Introduction}

Reproduction is one of the most important aspects of poultry breeding (Tadondjou et. al.2014).In male poultry reproduction is characterized by parameters, such as, age at sexual maturity ,fertility and sperm storage in female reprodctive tract (Addisu 2013).In hens, age at sexual maturity can be easily determined externally as age at which hens lay their first egg .Inversely, characterization is internal in male (Tandondjou et .al. 2014) .

Age at sexual maturity refers to age at which the reproductive system achieves its complete development .It has long been considered as an important factor that determines fecundity trait and affects subsequent performance (Forment et .al. 2009) .

Briere et .al.( 2011) reported that early male sexual maturity is associated with early decrease of fertility . At hen-house placement, rooster selected based on physical characteristics associated with reproductively mature male.Such, characteristics are comb, wattle size and color as well as over body size and strongly predictive of male fertility. Early semen collection was a valuable tool in the management of cocks (rooster) because it is considered the main objective of evaluating semen quality and to predict the fertility of an individual male. It seems that limited reference had been found for early response of semen collection (Saeki, 1962). The main objective of the present experiment was to evaluate the semen quality of roasters to select early sexual matured ones. Therefore selection for early sexual maturity can be done in both females and males to achieve more selection response than depending mainly on females.

\section{Materials And Methods}

The present experiment was carried out at Poultry Production Farm of Agricultural Faculty at Shebin Elkom, Menoufia University, Egypt. from May to December (2013). Forty four males of Norfa 13wks.of age strain - (i.e. is Egyptian synthetic strain of chicken which was developed at Poultry Production Farm of Agricultural Faculty at Shebin -Elkom, MenoufiaUniversity, Egypt (Abdou,1996 )) -Males were randomly selected (about 50\% from all cocks there at the same age ) and housed in individual cages under (step down 
step up ) photo period system. In addition, eighty four females at the same age were used .All birds were maintained on a layer commercial ration containing $17.46 \% \mathrm{CP}, 2699 \mathrm{ME}$.

Studied traits:

Studied traits were age at sexual maturity, body weight at sexual maturity, fertility, hatchability and egg weight at sexual maturity .Also, some of semen parameters included volume, PH, concentration of sperms per ml, motility and percent of normal shape were studied

Semen collection and evaluation:

Semen was collected weekly using the abdominal massage technique(Lake,1957). The first collection of semen at 13 wks. of age was used to study the age at the first response of collecting semen. Semen was collected in sterile and graduated tubes. Samples were used for laboratory evaluation of seminal parameters, within half an hour of collection .Parameters evaluated were ejaculated volume, motility, PH, percent of normal spermatozoa and concentration. Semen volume was measured when it had been collected into the graduated collecting tubes. Semen $\mathrm{pH}$ was measured by using PH meter. The semen collected was subjected to microscopic examinations and physical evaluations according to Zemjanis (1970) Cocks were divided into three groups according to the average of age at the first response of collecting semen and its standard deviation $(105.3 \pm 9.55$ d.). The first group was early response $\leq$ (mean-1 s.d).and the third was late response $\geq($ mean +1 s.d). Where, the second was median response included that every cock its first response of collecting semen ranged between the first and the third groups. In early group, the second and the third times of semen collection take places were after seven and fourteen day respectively, from the first response of colleting semen. Females were housed in individual cages at 18 wks. of age. Age at sexual maturity of hens was recorded at laying the first egg and egg weight at sexual maturity was the average of first five eggs weight. Females were divided into three groups according to the average of age at sexual maturity and its standard deviation (162.05 $\pm 22.17 \mathrm{~d}$.). The first group was early response $\leq($ mean $-0.5 \mathrm{~s} . \mathrm{d})$, and the third was late response $\geq($ mean $+0.5 \mathrm{~s} . \mathrm{d})$. Where, the second was median response included that every hens its sexual maturity ranged between the first and the third groups.

\section{Statistical analysis:}

Data collected were subjected to one way analysis variance (ANOVA) with following the statistical model

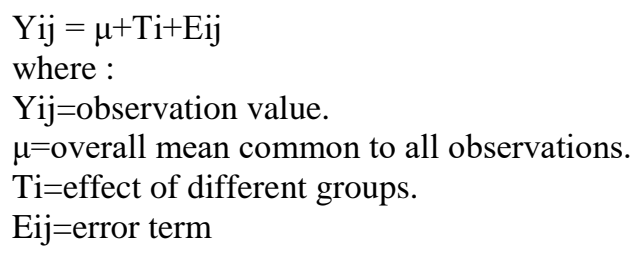

.All statistical analysis were performed using IBM SPSS Statistics for windows programmer version

\section{Results and Discussion}

The data in Table (1) show means, standard errors (S.E) of body weight and age at first response of semen collecting (AFR) in three groups divided according to (AFR). The values of B.W in early, median and late groups were 1059, 1075 and 1196.6 gm., respectively. While, the values of (AFR) in early, median and late groups were 91, 104.7 and 120.17 d., respectively. It was clear that showed that the percent of each group from the total cocks used in this experiment were $11.4 \%, 75 \%$ and $13.6 \%$ in early, median and late groups respectively. Fertility (in adult cocks) values in early, median and late groups were 85.3, 75.36 and $78.6 \%$, respectively. The means of B.W of cocks used in this study were in the range of $1005-1459 \mathrm{gm}$ as reported by El-wardany (1987), Enab (1991), Abou- El Ghar (1994), Zatter (1994), Enab et. al. (1995), Gomaa (1997) Harfoush (1997), Abou -El Ghar (2003) and Abou-Elewa (2010) in Norfa chickens.

The means of (AFR) of cocks used in this study agreed with results obtained in early previous study of Saeki (1962) who showed that differences in age at first semen production in New Hampshires and White Leghorns at 95d. of age. He reported that means of age at first semen production in New Hampshires and White Leghorns were 128.5 and $113.3 \mathrm{~d}$, respectively. He reported that percent of early response cocks (its AFR equal to $95 \mathrm{~d}$.) was $11.4 \%$. Table (1) shows that fertility in adult cocks in early group was greater than others.

The data in Table (2) showed means ,standard error (S.E) of age at sexual maturity, egg weight at sexual maturity (E.W) and hatchability in hens divided into three groups according to ASM.values of ASM in early ,median and late groups were 144,162.05 and 196 d., respectively. Means of E.W values in early, median and late groups were $37,40.13$ and $40.64 \mathrm{gm}$. Where hatchability values in early, median and late group were 
69.07.59.81 and 63.33\%, respectively. Means for ASM of females used in this study were found in the range of 139.3-184.9 d. which reported by El-Wardany(1987), Enab (1991), Enab et.al. (1992), Hassan (1993), Abou-El Ghar (1994), Zatter (1994), Abdou and Enab. (1994), Gomaa (1997), Abou-Elewa (2004) and Abou-Elewa (2010) in Norfa chickens. Egg weights at sexual maturity means were found in the range 34.4 - 44 gm of Norfa layers, in previous studies reported by El-Wardany (1987), Enab (1996), Gomaa (1997), and Abou-Elewa (2010). Table (2) shows that hatchability in adult early group was greater than others.

The data in Tables (3) and Table (4) show means, standard error (S.E) of some semen characteristics and ejaculated volume, sperm count, ph, percent of normal spermatozoa and motility levels at AFR.Values of sperm count in three groups were 38.7, 14.3 and $18.6109 / \mathrm{ml}$. and ejaculated volume in three groups were $0.32,0.36$ and $0.34 \mathrm{ml}$. and mean values of ph were 7.44, 7.49 and 7.49.respectively. Mean values of percent of normal spermatozoa in early, median and late group's were 33.2, 57.8 and $48.2 \%$ and initial motility after 3.-40 min. of collecting semen were 10.4, 15.4 and 11.04, respectively. Tables (5) and (6) showed analysis of variance of all studied traits. It was clear that there were no significant differences among all groups except AFR had highly significances $(\mathrm{p} \leq 0.01)$ between groups.

Table (7) shows some studies on semen parameters in chickens from 1997 to 2014. The means of ejaculated volume and $\mathrm{Ph}$ in Table (3) were agreed with results obtained in previous studies in Table (7). The means of sperm count, initial motility and percent of normal spermatozoa in Table (3) disagreed with results obtained in previous studies sperm count in previous studies in Table (7) range was 2.88-12.5 109/ml, but in this study sperm count in Table (3) was greater than this range in the three groups. Percent of normal spermatozoa and initial motility in Tables (3) and (4) were lower than others in Table (7). These differences may be caused by different ages of cocks at collecting and testing semen, .All of previous studies in Table (7) took place from 2548 wks. of age but in the recent study was took place at 13 wks. of age .Differences in initial motility between the recent study and the previous studies in Table (7) may be caused by time spent from collecting semen to time of the motility test ( test of motility was took place after 30-40 minutes from collecting semen ).

Figures 1 and 2 shows that direction of developed semen characteristics by the time from AFR during three weeks (one collection at week) figures show that as follows:

- Motility was increased by the time.

- Sperm count at AFR was greater than others.

- Percent of normal spermatozoa in the third group was little more than others.

- Ph was not different at the three times of collection.

\section{Concolusion}

- Males were earlier than females in age at sexual maturity.

- We would able to reduce breeding cost by using AFR to select early sexual maturity males before females sexual matured.

Early males sexual matured had the greatest fertility at maturation.

Early females sexual matured had the greatest hatchability at maturation.

Most of the experiments to decrease sexual maturity depend mainly on pullets; however, selection for decreasing this trait will be more effective using both males and females.

Table(1): The descriptive statistics on different groups of body weight (B.W), age at first response of semen collecting (AFR)and fertility in adult Norfa cocks.

\begin{tabular}{|c|c|c|c|c|c|c|}
\hline \multirow[t]{2}{*}{ Group } & \multicolumn{6}{|c|}{ mean \pm S.E } \\
\hline & No. & B. $W^{*}$ & No. & AFR.** & No. & Fertility (\%) \\
\hline Early & 5 & 1059 gm. \pm 50.8 & 5 & $91 d . \pm 0.0$ & 4 & $85.3 \pm 5.4$ \\
\hline Median & 30 & $1075 \mathrm{gm} . \pm 27.2$ & 33 & $104.7 d . \pm 1.2$ & 9 & $75.36 \pm 9.5$ \\
\hline Late & 6 & $1196.6 \mathrm{gm} . \pm 79.1$ & 6 & $120.17 d . \pm 1.2$ & 1 & $78.6 \pm 0.0$ \\
\hline All & 41 & $1091.2 \mathrm{gm} . \pm 24.2$ & 44 & $105.3 d . \pm 1.5$ & 14 & $78.45 \pm 6.2$ \\
\hline
\end{tabular}

B. $W^{*}$ : body weight at age at first response of semen collecting, AFR. **: age at first response of semen collecting.

Table(2): The descriptive statistics on different groups of egg weight (E.W), age at sexual maturity (ASM,)and hatchability in adult Norfa layers.

\begin{tabular}{|c|c|c|c|c|c|}
\hline \multirow[t]{2}{*}{ Group } & \multicolumn{5}{|c|}{ mean \pm S.E } \\
\hline & No. & $A S M^{*}$ & $E . W^{* * *}$ & No. & Hatchability(\%) \\
\hline Early & 29 & $144 d . * * * \pm 1.1$ & $37.1 \mathrm{gm} . \pm 0.48$ & 13 & $69.07 \pm 6.94$ \\
\hline Median & 38 & $162.05 \mathrm{~d} . \pm 0.4$ & $40.13 \mathrm{gm} . \pm 0.46$ & 10 & $59.81 \pm 9.07$ \\
\hline Late & 17 & $196 d . \pm 6.3$ & 40.64 gm. \pm 0.73 & 6 & $63.33 \pm 16.6$ \\
\hline All & 84 & $162.82 d . \pm 2.4$ & $39.20 \mathrm{gm} . \pm 0.34$ & 29 & $64.68 \pm 5.41$ \\
\hline
\end{tabular}

ASM*: age at sexual maturity, E.W**:egg weight at sexual maturity. , d.:day 
Table(3): The descriptive statistics on different groups of semen parameters in Norfa cocks.

\begin{tabular}{|c|c|c|c|c|c|}
\hline \multirow[t]{2}{*}{ Group } & \multicolumn{5}{|c|}{ mean $\pm S . E$} \\
\hline & No & count $\times 10^{9}$ & Volume (ml.) & $P H$ & \% normality \\
\hline Early & 5 & $38.7 \pm 34.1$ & $3.2 \pm 0.1$ & $7.44 \pm 0.4$ & $33.25 \pm 11.7$ \\
\hline Median & 33 & $14.3 \pm 4.8$ & $3.6 \pm 0.1$ & $7.49 \pm 0.2$ & $57.8 \pm 4.0$ \\
\hline Late & 6 & $18.6 \pm 6.19$ & $3.4 \pm 0.3$ & $7.49 \pm 0.05$ & $48.2 \pm 13.3$ \\
\hline All & 44 & $17.7 \pm 5.2$ & $3.5 \pm 0.1$ & $7.49 \pm 0.02$ & $53.7 \pm 3.8$ \\
\hline
\end{tabular}

Table(4): The descriptive statistics on different groups of percent of sperm motility levels (after 30-40 min from collecting semen) in Norfa cocks.

\begin{tabular}{|l|l|l|l|l|l|}
\hline \multirow{2}{*}{ Group } & mean \pm S. & \multicolumn{5}{l|}{} \\
\cline { 2 - 6 } & No. & $\boldsymbol{A}^{*}$ & $\boldsymbol{B}$ & $\boldsymbol{C}$ & \multicolumn{1}{l|}{} \\
\hline Early & 5 & $10.4 \pm 3.7$ & $10.8 \pm 3.7$ & $15.3 \pm 4.8$ & $52.6 \pm 15.3$ \\
\hline Median & 33 & $15.4 \pm 1.2$ & $18.3 \pm 1.2$ & $16.7 \pm 0.9$ & $49.47 \pm 6$ \\
\hline Late & 6 & $11.04 \pm 3.0$ & $16.3 \pm 2.1$ & $13.09 \pm 2.8$ & $46.7 \pm 11.8$ \\
\hline All & 44 & $14.27 \pm 0.2$ & $17.2 \pm 1.1$ & $16.1 \pm 0.09$ & $49.4 \pm 2.9$ \\
\hline
\end{tabular}

$A^{*}, B, C, D$ :sperm motility levels

Table(5): Analysis of variance of body weight (B.W) and fertility in Norfa cocks.

\begin{tabular}{|l|l|l|l|l|}
\hline \multirow{2}{*}{ s.o.v } & \multicolumn{3}{|l|}{$\boldsymbol{W}$} & $\boldsymbol{F}$ Fertility \\
\cline { 2 - 5 } & $\boldsymbol{d . f}$ & $\mathbf{S} \boldsymbol{S}$ & $\boldsymbol{d} . \boldsymbol{f}$ & M.S \\
\hline total & 40 & & 14 & \\
\hline group & 2 & 39659.09 & 2 & 138.7 \\
\hline error & 38 & 23245.28 & 13 & 628.1 \\
\hline
\end{tabular}

Table(6): Analysis of variance of age at first response of semen collecting (AFR) and some semen parameters.

\begin{tabular}{|l|l|l|l|l|l|l|l|}
\hline \multirow{2}{*}{ s.o.v } & \multirow{2}{*}{$\boldsymbol{f}$} & AFR* & $\begin{array}{l}\text { Sperm } \\
\text { count }\end{array}$ & volume & $\boldsymbol{P H}$ & $\begin{array}{l}\text { A(initial } \\
\text { motility) }\end{array}$ & normality \\
\cline { 3 - 8 } & & M.S. & & & & & \\
\hline Total & 43 & & 1291.9 & 0.485 & 0.007 & 91.78 & 1412.74 \\
\hline Group & 2 & $6616.238^{* *}$ & 1209.285 & 0.21 & 0.013 & 54.47 & 609.738 \\
\hline Error & 41 & 38.01 &
\end{tabular}

AFR*: age at first response of semen collecting.

- $*$ *highly significant $(\mathbf{p}<0.01)$

Table(7): Some previous studies on semen parameters in chickens.

\begin{tabular}{|c|c|c|c|c|c|c|c|c|}
\hline Author & $\begin{array}{l}\text { Published } \\
\text { year }\end{array}$ & Bred/strain/line & $\begin{array}{l}\text { sperm } \\
\text { count } \\
x 10^{9} / \mathrm{ml}\end{array}$ & $\begin{array}{l}\text { ejaculated } \\
\text { volume }(\mathrm{ml})\end{array}$ & $\begin{array}{l}\text { \%Normal } \\
\text { spermatozoa }\end{array}$ & $P H$ & $\begin{array}{l}\text { initial } \\
\text { motility }\end{array}$ & Age \\
\hline $\begin{array}{l}\text { Mohan } \\
\text { et.al. }\end{array}$ & 1997 & Male broiler & $\begin{array}{ll}2.94 & - \\
4.66 & \end{array}$ & $0.29-0.44$ & $85.2-92.6$ & & & different age \\
\hline $\begin{array}{l}\text { Gebriel } \\
\text { et.al }\end{array}$ & 2009 & Norfa & 3.81 & 0.33 & 84.64 & 7.27 & 75.6 & different age \\
\hline Murugesan & 2012 & Nacked neck & $\begin{array}{ll}2.88 \quad- \\
5.8\end{array}$ & $0.21-0.43$ & $99.17-99.9$ & & & different age \\
\hline Murugesan & 2012 & Dwarf & $\begin{array}{ll}4.37 & - \\
5.39 & \end{array}$ & $0.34-0.48$ & $99.55-99.88$ & & & different age \\
\hline Tarif et.al. & 2013 & $\begin{array}{l}\text { Sasso } \\
\text { lines }(1,2,3)\end{array}$ & $9.2-9.9$ & $770-800 \mu l$ & $87-90.3$ & & $81.7-85$ & $40 w k$. \\
\hline Tarif et.al. & 2013 & $\begin{array}{l}\text { Synthetic } \\
\text { lines }(1,2,3)\end{array}$ & $8.6-9.5$ & $530-670 \mu l$ & $88.7-89.7$ & & $73-78.3$ & $40 w k$. \\
\hline Tarif et.al. & 2013 & $\begin{array}{l}\text { Rock } \\
\text { lines }(1,2,3)\end{array}$ & $7.7-8.9$ & $470-500 \mu l$ & $87-89$ & & 78.3 & $40 w k$. \\
\hline $\begin{array}{l}\text { Churcil } \\
\text { et.al. }\end{array}$ & 2014 & Rod Island Red & 4.03 & 0.38 & 95.48 & & & 12 months \\
\hline $\begin{array}{l}\text { Tadonjou } \\
\text { et.al. }\end{array}$ & 2014 & $\begin{array}{l}\text { Local barred } \\
\text { cock }\end{array}$ & $3.8-12.5$ & $81.6-146.6 \mu l$ & & & & different age \\
\hline $\begin{array}{l}\text { Abou- } \\
\text { Elnaga }\end{array}$ & 2014 & Norfa & 3.79 & & 76 & & 68.33 & $40 w k$ \\
\hline
\end{tabular}




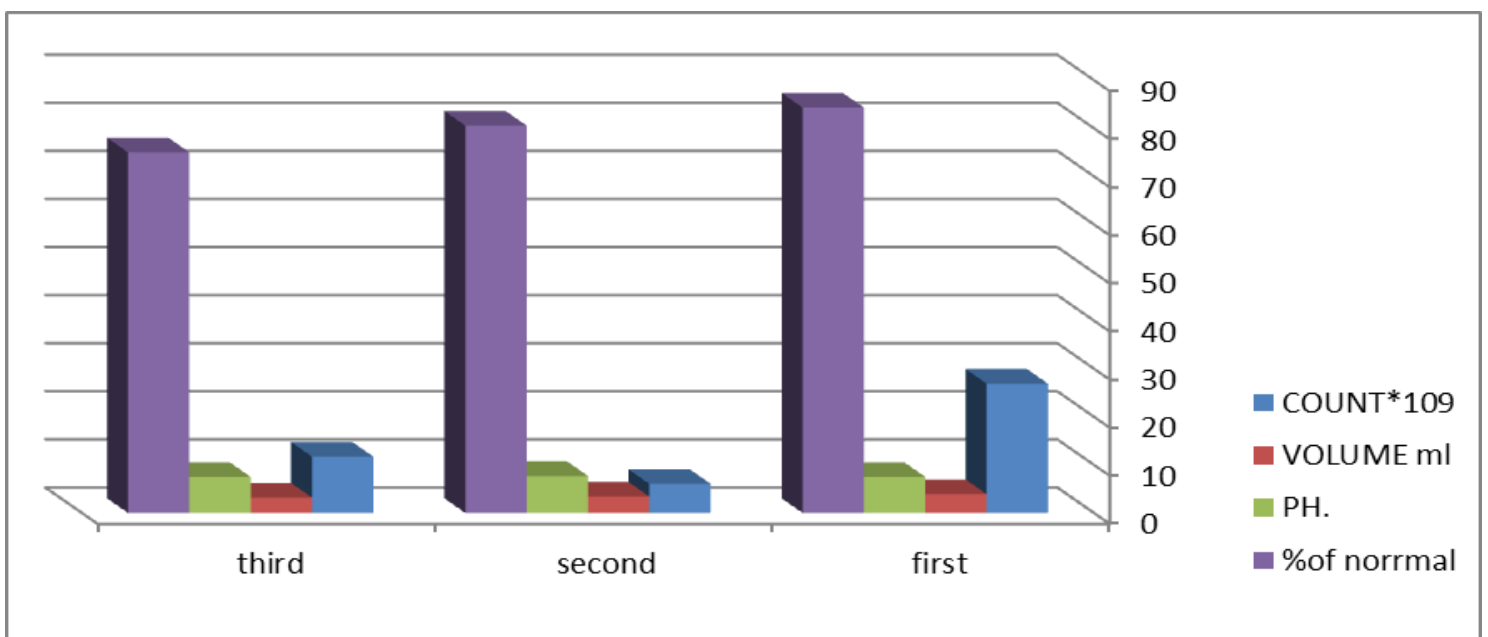

Figure (1):developing some semen parameters during the first ,second and third weeks of semen collecting response.

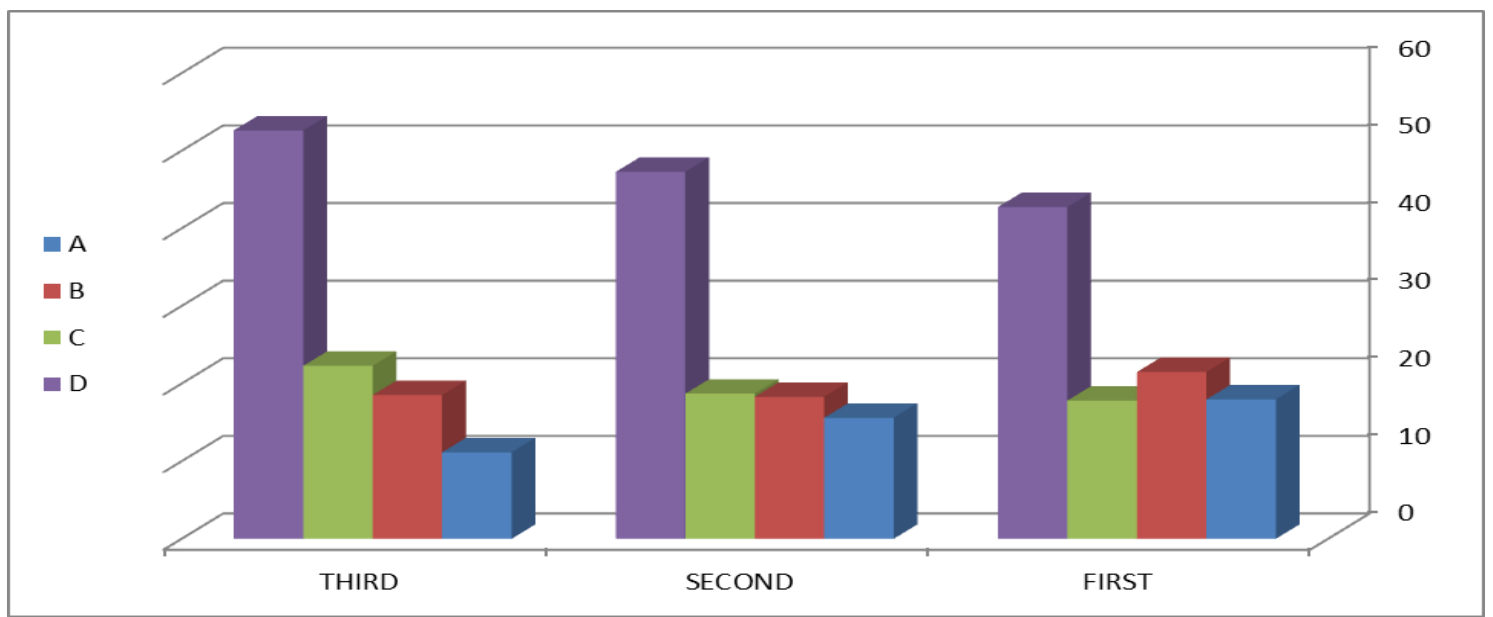

Figure (2):developing of motility levels during the first ,second and third weeks of semen collecting response.

\section{References}

[1] Abdou,F.H.(1996):Improving indigenous breeds :experience from Egypt, Norway and Tanzania. Egypt.J.Anim.Produ.33:567-576.

[2] Abdou F.H. and Enab A.A. (1994): A comparison between the efficiencies of restricted selection indices with different levels of restriction in selection breeding programs for laying hens .Proc. $2^{\text {nd }}$ scientific conf. on Poultry Tanta Univ.Kafer EL-Sheikh, Egypt .

[3] Abou-Elewa E.M. ( 2004): Selection for general immune response and its relation to some economic traits in chickens. M.s.c. Thesis, Fac. Of agric. Menoufia, Univ. Egypt.

[4] Abou-Elewa E.M. ( 2010): Some genetic parameters of the immune response trait and its utilization in different selection methods in chickens. Ph.D. Thesis, Fac. Of agric. Menoufia, Univ. Egypt.

[5] Abou- El Ghar R. (1994): Genetic studies of some productive traits in chickens.M.s.c. Thesis, Fac. Of agric. Menoufia, Univ. Egypt.

[6] Abou -El Ghar R. (2003):Combining ability and genetic gain of some economic traits in Norfa chickens. Ph.D. Thesis, Fac. Of agric. Menoufia, Univ. Egypt.

[7] Addisu H.(2013): Phenotypic characterization of indigenous chicken ecotypes in Northwollo , Amhara Regional State, Ethiopia.Master's thesis . Edition Find Knowledge, document $N^{\circ}$ V206157,ISBN 978-656-34128-4;87pages.

[8] Briere S. Brillard JP, Panheleux M and Froment P. ( 2011): Alimentation, fertilitē et bien-etre des oiseaux reproducteurs domestiqes:Des liens complexes. INRA Prod. A nim. ,24:171-180.

[9] El-Wardany A.(1987): Using different methods of selection in chickens .Ph.D. Thesis , Fac. Of agric. Menoufia, Univ. Egypt.

[10] Enab A.A. (1991): The using of different selection indices to improve some economic traits in laying hens . Ph.D. Thesis, Fac. Of agric. Menoufia, Univ. Egypt.

[11] Enab A.A. (1996): Genetic progress achieved in some egg production traits by using supplementary family information in selection indices. Egypt .Poult. Sci. ,16:25-267.

[12] Enab A.A.; M.Soltan; F.H.Abdou and G. Gebreil (1992): Two stage selection index in Norfa chickens.Menoufia J.Agric Res, $17: 1917-1938$

[13] Enab A.A. ; B.T. Sherief A.M.El-Wardany and F.H.Abdou (1995): Genetic response of some economic traits in Norfa chickens divergently selected for body weight . First Egyptian Hungarian Poult. Conf. 17-19 September, Alexandria, Egypt,207-217.

[14] Forment P.Ouste C.Pelletier R. and Brillard JP.( 2009):Rôle de L'AMP-activated protein kinase dans l'activitē des cellules de Sertoli de coq immature (Gallus domesticus).Huitimes Journēes de la recherché avicole, St Malo., 25 et 26 mars.

[15] Gomaa M.(1997): Effect of light and temperature on performance of chickens M.s.c. Thesis, Fac. Of agric. Menoufia, Univ. Egypt.. 
[16] Harfoush M. (1997):A study on the effects of some genetic and environmental factors on egg production of chickens of chickens. M.s.c. Thesis, Fac. Of agric. Menoufia, Univ. Egypt.

[17] Hassan (1993): Inheritance of some constituents of blood serum and their relationship with production traits in Alexandria and Norfa chickens. M.s.c. Thesis , Fac. Of agric. Alex., Univ.Egypt.

[18] Saeki Y.(1962):.Fertilizing ability of cock spermatozoa first ejaculated and changes in semen quality with age of cock.Jap.J.Zootech.Sci.,34,(2):121-125.

[19] Tadondjou C.D.A.,Ngoula F., Kana J.R.,Mube H.K. and Teguia A.(2014): Characterization of reproduction of local Barred male chicken of the Western Highlands of Cameroon: Sexual maturity ,fertility and sperm storage term in female. J. Phys .Pharm Adv 2014,4(2):323-331.

[20] Zemjanis R. (1970): Collection and evaluation of semen diagnostic and therapeutic in animal reproduction. $2^{\text {nd }}$ Edn., Williams and Wilkins Co.Baltimore M.D.,pp:139:156.

Abou-Elewa E.M. "Sexual Maturity of Male Chickens According To Early Response of Semen Collection." IOSR Journal of Agriculture and Veterinary Science (IOSR-JAVS) 10.7 (2017): 58-63. 